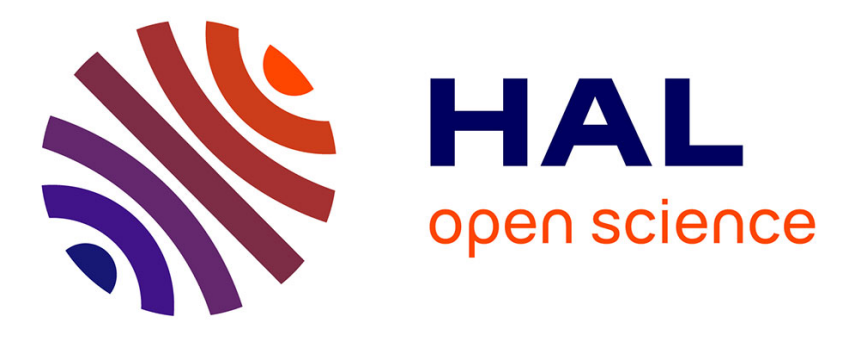

\title{
Pertinent plasma indicators of the ability of chickens to synthesize and store lipids
}

Elisabeth Baéza, Maëva Jégou, Florence Gondret, J Lalande-Martin, I Tea, Elisabeth Duval, Cécile Berri, Anne Collin, Sonia Metayer-Coustard, Isabelle Louveau, et al.

\section{To cite this version:}

Elisabeth Baéza, Maëva Jégou, Florence Gondret, J Lalande-Martin, I Tea, et al.. Pertinent plasma indicators of the ability of chickens to synthesize and store lipids. Journal of Animal Science, 2015, 93 (1), pp.107-116. 10.2527/jas.2014-8482 . hal-01207761

\section{HAL Id: hal-01207761 \\ https://hal.science/hal-01207761}

Submitted on 27 May 2020

HAL is a multi-disciplinary open access archive for the deposit and dissemination of scientific research documents, whether they are published or not. The documents may come from teaching and research institutions in France or abroad, or from public or private research centers.
L'archive ouverte pluridisciplinaire HAL, est destinée au dépôt et à la diffusion de documents scientifiques de niveau recherche, publiés ou non, émanant des établissements d'enseignement et de recherche français ou étrangers, des laboratoires publics ou privés. 


\title{
Pertinent plasma indicators of the ability of chickens to synthesize and store lipids ${ }^{1}$
}

\author{
E. Baéza,*2 M. Jégou, † F. Gondret, † J. Lalande-Martin,§ I. Tea,§ E. Le Bihan-Duval,* C. \\ Berri,* A. Collin,* S. Métayer-Coustard,* I. Louveau, $\uparrow+$ S. Lagarrigue, $\uparrow+$ and M. J. Duclos* \\ *INRA, UR83 Recherches Avicoles, F-37380 Nouzilly, France; †INRA, UMR1348 \\ Physiologie, Environnement et Génétique pour l'Animal et les Systèmes d'Elevage (PEGASE), F-35590 \\ Saint-Gilles, France; \$Agrocampus-Ouest, UMR 1348 PEGASE, F-35590 Saint-Gilles, France; §Faculté des \\ Sciences et Techniques, UMR CNRS 6230 CEISAM, BP 92208, 2 Rue de la Houssinière, F-44322 Nantes Cedex 3
}

\begin{abstract}
Excessive deposition of body fat is detrimental to production efficiency. The aim of this study was to provide plasma indicators of chickens' ability to store fat. From 3 to 9 wk of age, chickens from 2 experimental lines exhibiting a 2.5 -fold difference in abdominal fat content and fed experimental diets with contrasted feed energy sources were compared. The diets contained 80 vs. $20 \mathrm{~g}$ of lipids and 379 vs. $514 \mathrm{~g}$ of starch per $\mathrm{kg}$ of feed, respectively, but had the same ME and total protein contents. Cellulose was used to dilute energy in the high-fat diet. At 9 wk of age, the body composition was analyzed and blood samples were collected. A metabolome-wide approach based on proton nuclear magnetic resonance spectroscopy was associated with conventional measurements of plasma parameters. A metabolomics approach showed that betaine, glutamine, and histidine were the most discriminating metabolites between groups. Betaine, uric
\end{abstract}

acid, triglycerides, and phospholipids were positively correlated $(r>0.3 ; P<0.05)$ and glutamine, histidine, triiodothyronine, homocysteine, and $\beta$-hydroxybutyrate were negatively correlated $(r<$ $-0.3 ; P<0.05)$ with relative weight of abdominal fat and/or fat situated at the top of external face of the thigh. The combination of plasma free fatty acids, total cholesterol, phospholipid, $\beta$-hydroxybutyrate, glutamine, and methionine levels accounted for $74 \%$ of the variability of the relative weight of abdominal fat. On the other hand, the combination of plasma triglyceride and homocysteine levels accounted for $37 \%$ of the variability of fat situated at the top of external face of the thigh. The variations in plasma levels of betaine, homocysteine, uric acid, glutamine, and histidine suggest the implication of methyl donors in the control of hepatic lipid synthesis and illustrate the interplay between AA, glucose, and lipid metabolisms in growing chickens.

Key words: chicken, energy metabolism, fat deposition, lipids, plasma markers, starch

(C) 2015 American Society of Animal Science. All rights reserved. $\quad \begin{array}{r}\text { J. Anim. Sci. 2015.93:107-116 } \\ \text { doi:10.2527/jas2014-8482 }\end{array}$

\section{INTRODUCTION}

In animal production, fat is usually considered to be a byproduct of very low commercial value. Moreover, fatty animals are less efficient in the conversion of feed

\footnotetext{
${ }^{1}$ The authors thank the staff of the INRA experimental poultry unit (UE1295 PEAT, Nouzilly, France) for producing and rearing animals and the technicians of the research units for measurements on birds, sample collection, and laboratory analyses. This project was supported by the French ANR FatInteger program (ANR-11-BSV7-0004).

${ }^{2}$ Corresponding author: baeza@tours.inra.fr

Received September 5, 2014.

Accepted November 7, 2014.
}

during the rearing period and therefore do not contribute to the profitability of meat production. Then, breeders have selected chickens for many years for low carcass fatness. One of the main problems associated with this selection arises from the need to slaughter birds to measure the relative proportion of abdominal fat and to use collateral birds for breeding purposes. In addition, experimental lines have been divergently selected for low or high abdominal fat to increase our understanding of the genetic regulation of adiposity and energy metabolism in meat-type chickens (Leclercq, 1988). Beside genetics, diet composition may also influence body composition and tissue metabolisms, because 
nutrient sensors in tissues regulate energy homeostasis (Hardie et al., 2012). To date, targeted approaches (see Baéza and Le Bihan-Duval, 2013, for review) and transcriptomic analyzes of different tissues (Lagarrigue et al., 2006; Bourneuf et al., 2006; Resnyk et al., 2013) have been performed in fat and lean lines eventually considering their nutritional status to unravel the relationships between body fatness and energy and protein metabolisms as well as the endocrine regulation of lipogenesis. Easily accessible fluids such as blood also offer opportunities to screen tissue metabolism interplay and to search some indicators of body fatness that may be later tested for selection procedure (Leclercq et al., 1987). Broader explorations of genetics and nutritional interaction effects have been recently challenged by the development of untargeted genomewide approach technologies on plasma such as metabolomics; this, however, has been rarely applied to chickens (Huber et al., 2010). That is why a metabolome-wide approach on plasma, associated with conventional blood biochemistry, was undertaken to provide indicators of energy metabolism adaptation when chickens of different genetics ability to synthesize and store lipids were faced with diets with contrasted energy sources.

\section{MATERIALS AND METHODS}

\section{Experimental Design}

All experimental procedures were performed in accordance with the French national guidelines for the care and use of animals for research purposes (certificate of authorization to experiment on living animals number 7740, Ministry of Agriculture and Fish Products, and favorable notice of ethics committee of "Val de Loire," March 3, 2012). A total of 120 males from 2 experimental lines (60 per line) divergently selected on abdominal fat content (fat vs. lean; Leclercq, 1988) were obtained from the experimental unit Pôle Expérimental Avicole de Tours (INRA, Nouzilly, France) on the day of hatching. Chickens were reared together in a closed building (6.7 birds $\left./ \mathrm{m}^{2}\right)$ and fed a starting diet (2,900 ME kcal/kg and $210 \mathrm{~g} \mathrm{CP} / \mathrm{kg}$ ). At $21 \mathrm{~d}$ of age, 32 chickens per line of similar BW were distributed into 2 groups receiving 1 of the 2 experimental diets and placed in individual cages ( 60 by 45 by $60 \mathrm{~cm}$ per cage). To limit the genetic variation, 2 or 4 brothers from a same family (1 sire crossed with 1 dam) were equally distributed between the 2 dietary groups. The diets were isoenergetic and isoproteic but exhibited a low lipid (LL) or a high lipid (HL) content. Cellulose was used to dilute energy in the HL diet. The percentages of SFA, MUFA, and PUFA were similar in the HL and LL diets. The experimental growing diets (12.54 MJ ME/kg and $190 \mathrm{~g} \mathrm{CP} / \mathrm{kg}$ ) were given from
21 to $63 \mathrm{~d}$. At this age, 12 chickens per group were feed deprived for $12 \mathrm{~h}$ and then refed for $3 \mathrm{~h}$ before being sacrificed by decapitation and bleeding. The growth performance, body composition, and metabolic characterization of the liver, abdominal fat, and pectoralis major (PM) and sartorius (SART) muscles were reported by Baéza et al. (2014; Table 1).

At $20 \mathrm{~d}$ of age (early stage before distribution of experimental diets) and just before sacrifice, at $63 \mathrm{~d}$ of age, blood samples were collected in the occipital sinus in tubes containing EDTA or heparin and kept on ice. After centrifugation $\left(2,000 \times \mathrm{g}\right.$ for $10 \mathrm{~min}$ at $\left.4^{\circ} \mathrm{C}\right)$, aliquots of plasma were stored at $-20^{\circ} \mathrm{C}$ for later analyses of targeted plasma parameters or $-80^{\circ} \mathrm{C}$ for proton nuclear magnetic resonance ( ${ }^{\mathbf{1}} \mathbf{H}$ NMR)-based metabolomic investigations (only in 63-d-old chickens).

\section{Targeted Plasma Parameters}

Plasma triglyceride, total cholesterol, phospholipids, free fatty acids (FFA), glucose, lactate, uric acid, urea, and $\beta$-hydroxybutyrate were quantified by colorimetric enzymatic methods using a Konelab 20 analyzer (Thermo Scientific, Gometz le Châtel, France) and kits provided by Bio-Mérieux (Marcy-l'Etoile, France), Sobioda (Montbonnot, France), and Thermo Scientific (Villebon sur Yvette, France). Plasma insulin levels were determined by RIA as previously described (Simon et al., 1974). Triiodothyronine (T3) and thyroxin (T4) levels were determined by RIA as previously described (Van der Geyten et al., 2002). Plasma homocysteine level was quantified by ultra performance liquid chromatography-high resolution mass spectrometry within an injection interval of $2.05 \mathrm{~min}$ (isocratic mix at 0.6 $\mathrm{mL} / \mathrm{min}$ with $60 \%$ acetonitrile and $40 \%$ water containing $0.1 \%$ formic acid; column Kinetex ${ }^{\circledR}$ XB-C18 1.7 $\mu \mathrm{m} 100 \mathrm{~nm}, 150 \mathrm{~mm}$ by $2.1 \mathrm{~mm}$; Phenomex ${ }^{\circledR}$, Torrance, $\mathrm{CA}$; injection of $1 \mu \mathrm{L}$ and oven temperature at $60^{\circ} \mathrm{C}$ ) after a 2-step sample preparation (reduction followed by precipitation of the protein matrix) with the ClinMass ${ }^{\circledR}$ (Recipe $^{\circledR}$; Precision Instruments, Marseille, France).

\section{Untargeted Plasma Metabolomics}

For ${ }^{1} \mathrm{H}$ NMR spectroscopy, samples were prepared from a plasma volume of $150 \mu \mathrm{L}$ and $450 \mu \mathrm{L}$ of a mixture of $\mathrm{H}_{2} \mathrm{O} /$ deuterium oxide (10/90\% volume) added in a $5-\mathrm{mm}$ nuclear magnetic resonance (NMR) tube. High-resolution NMR spectra of all blood plasma were recorded on a Bruker Avance DRX-500 spectrometer (Bruker, Karlsruhe, Germany), operating at 500.13 $\mathrm{MHz}$ and equipped with a cryogenic probe. ${ }^{1} \mathrm{H}$ NMR spectra were acquired at $303 \mathrm{~K}$ using the 1-dimensional nuclear overhauser effect spectroscopy and pulse se- 
quence comprising a relaxation delay $(\mathrm{RD})$ of $4 \mathrm{~s}$, a mixing time $\left(\mathrm{t}_{\mathrm{m}}\right)$ of $150 \mathrm{~ms}$ and a fixed delay $\left(\mathrm{t}_{1}\right)$ of $20 \mu \mathrm{s}$. Water suppression was achieved by presaturation during the relaxation delay and mixing time at $90^{\circ} \mathrm{C}$. Each spectrum consisted of 256 free induction decays (FID) collected into 32,000 complex data points with a spectral width of $12.10^{-6} \mathrm{~m}$ and an acquisition time of 2 s. Data were processed using Topspin software (Bruker) with 1 level of zero-filling and Fourier transformation after multiplying FID by an exponential line broadening function of $0.3 \mathrm{~Hz}$. The 1-dimensional NMR spectra were manually phase and baseline corrected and referenced to the chemical shift of the $\alpha$-glucose at $\delta 5.235$.

\section{Statistical and Chemometric Data Analyses}

The experimental unit was the bird. There were 4 treatments representing a factorial 2 , line and diet. The effects of line, diet, and their interaction on plasma targeted metabolites were tested by ANOVA (R 3.0.2 statistical software; R Development Core Team, 2004) and means were compared with a $t$-test and a significance level at $P<0.05$.

${ }^{1} \mathrm{H}$ NMR spectra were transferred to the AMIX software (version 3.8.4; Bruker). The bin area method was used to segment the spectra between 0.6 and 8.5.10 $0^{-6} \mathrm{~m}$ using the intelligent variable size bucketing tool. The spectral regions containing water $(4.4-5.1)$ and EDTA signals (2.53-2.58, 2.68-2.70, 3.05-3.23, and 3.60-3.64) were excluded. One hundred ten buckets were manually defined and covered $99.5 \%$ of the spectrum. One bucket corresponded to 1 variable (part of 1 and more metabolites according to NMR signal assignment). Bin areas generated a matrix consisting of rows representing 48 samples and columns representing 110 variables. The data set was normalized by dividing each integrated segment by the total area of the spectrum. The new matrix thus obtained was subjected to statistical analyses. For metabolomics data, discriminating variables were first uncovered through a supervised univariate approach with $t$-tests and boxplots, using the R 3.0.2 software. After mean centering and autoscaling, the data matrix was subjected to several multivariate statistical analyses using SIMCA-P+ 12.0 software (Umetrics, Umeå, Sweden). Principal component analysis was used first. It is an unsupervised method that requires no prior knowledge of the data set and that describes the greatest amount of variance. Principal component analysis is useful for outlier detection and for finding patterns and trends. Therefore, the $1 \mathrm{H}$ NMR data set was then handled using a supervised method such as projections to latent structure by partial least squares-discriminant analysis (PLS-DA). The predictive feature of the PLS-DA models was vali- dated using the values of three parameters: the predictive ability parameter (Q2) which reflects the model's potential for predicting class membership (Anderssen et al., 2006), the proportion of the total variance (i.e., the class of each experimental group) of the response variable explained by the model (R2Y) and the proportion of the total variance of the dependent variables that is explained by the model (R2X). The statistical significance of the R2Y and Q2 parameters was estimated through a response permutation test, where the $\mathrm{Y}$ matrix is randomly permuted 999 times when the $\mathrm{X}$ matrix is fixed (Eriksson et al., 2008). Finally, a $P$-value was generated from a cross-validated ANOVA (Eriksson et al., 2008). Loading plot, coefficient plot, and variable importance in the projection (VIP) from PLS-DA models were used to identify the metabolites driving the separation between classes. In this study, 4 criteria were used to validate the PLS-DA models: 1) $\mathrm{Q}^{2}$ $>0.5,2) \mathrm{CV}$-ANOVA $<0.05,3)$ response permutation test, and 4) visual analysis of the boxplots and $P<0.05$ for the metabolites arising from the coefficient plot and VIP. The PLS-DA models were considered predictive if 3 out of these 4 criteria were correct. In addition, the effect of line, diet, and their interaction were also tested on each metabolite by ANOVA (R 3.0.2. software) and a significance level at $P<0.05$.

Finally, the relationships between body composition and plasma profile were analyzed by calculating simple linear regression analyses between the weights of abdominal fat; fat situated on the top of the external face of the thigh (FTET); PM and SART muscles, relative to body weight; and concentration of each metabolite or hormone (R 3.0.2. software). Data were then further tested using a stepwise multiple linear regression.

\section{RESULTS}

\section{Feed Consumption and Body Composition}

No interaction $(P>0.10)$ between diet and line was observed for the feed consumption and body composition of chickens. The diet had no effect on the feed consumption and body composition at $63 \mathrm{~d}$ of age $(P>$ $0.10)$. Irrespective of the diet, lean chickens displayed lower ADFI $(P<0.0001)$ than fat chickens over the growth period considered. Lean chickens had higher muscle yield but lower carcass fatness than fat chickens $(P<0.05)$, as illustrated by the $63 \%$ reduction in abdominal fat proportion.

\section{Targeted Plasma Parameters}

At $20 \mathrm{~d}$ of age, chickens of the lean line had higher triglyceridemia $(+21 \% ; P<0.05)$ and glycaemia 
Table 1. Effect of line (fat and lean) and diet (high lipid [HL] and low lipid [LL]) on the feed consumption during the experimental period and body composition of chickens at $63 \mathrm{~d}$ of age $(\% \mathrm{BW}$; mean $\pm \mathrm{SE} ; n=12)$

\begin{tabular}{lccccc}
\hline \hline Groups & $\begin{array}{c}\text { ADFI 22-63 d, } \\
\mathrm{g} \cdot \mathrm{d}^{-1} \text { per chicken }\end{array}$ & $\begin{array}{c}\text { Abdominal } \\
\text { fat }\end{array}$ & $\begin{array}{c}\text { Fat situated on the } \\
\text { top of the thighs }\end{array}$ & $\begin{array}{c}\text { Pectoralis } \\
\text { major muscle }\end{array}$ & $\begin{array}{c}\text { Sartorius } \\
\text { muscle }\end{array}$ \\
\hline Fat-LL & $114 \pm 8$ & $3.5 \pm 0.6$ & $0.5 \pm 0.1$ & $4.2 \pm 0.3$ & $0.62 \pm 0.06$ \\
Fat-HL & $113 \pm 10$ & $3.3 \pm 0.9$ & $0.3 \pm 0.1$ & $4.2 \pm 0.2$ & $0.60 \pm 0.04$ \\
Lean-LL & $101 \pm 9$ & $1.1 \pm 0.5$ & $0.2 \pm 0.1$ & $4.4 \pm 0.2$ & $0.65 \pm 0.06$ \\
Lean-HL & $102 \pm 5$ & $1.4 \pm 0.7$ & $0.2 \pm 0.2$ & $4.4 \pm 0.4$ & $0.63 \pm 0.07$ \\
Diet effect & 0.88 & 0.77 & 0.18 & 0.88 & 0.28 \\
Line effect & 0.0001 & 0.0001 & 0.0004 & 0.025 & 0.04 \\
Diet $\times$ line effect & 0.71 & 0.26 & 0.17 & 0.75 & 0.89 \\
\hline
\end{tabular}

$(+12 \% ; P=0.0006)$ compared with the chickens of the fat line (Table 2). Plasma concentrations of phospholipids, $\beta$-hydroxybutyrate, total cholesterol, FFA, uric acid, and urea were not affected by the line. The lean chickens also exhibited lower concentrations of T4 $(-20 \% ; P=0.03)$ than the fat chickens whereas T3 and insulin plasma concentrations did not differ between the 2 lines (Table 2).

At $63 \mathrm{~d}$ of age, the line had no effect on plasma levels of total cholesterol, phospholipids, FFA, lactate, urea, T3, and T4 (Table 3). The fat chickens had higher plasma levels of triglycerides $(+31 \% ; P=0.02)$ and uric acid $(+37 \% ; P<0.0001)$ but lower levels of glucose $(-6 \% ; P=0.02), \beta$-hydroxybutyrate $(-20 \% ; P=$ $0.006)$, insulin $(-25 \% ; P=0.02)$, and homocysteine $(-23 \% ; P=0.002)$ than the lean chickens. The diet had no effects on plasma levels of triglycerides, glucose, lactate, urea, T3, and T4 (Table 3). The chickens fed the LL diet had higher plasma levels of total cholesterol $(+14 \% ; P=0.006)$, phospholipids $(+16 \%$; $P=0.0009), \beta$-hydroxybutyrate $(+28 \% ; P=0.002)$, and uric acid $(+35 \% ; P<0.0001)$ and lower levels of FFA $(-41 \% ; P<0.0001)$ and homocysteine $(-15 \%$; $P=0.04)$ than chickens fed the HL diet. For T3 and glucose plasma levels, there was an interaction between the line and diet. For T3 plasma level, the lean chickens fed the LL diet exhibited the highest value whereas the fat chickens fed the LL diet exhibited the lowest value $(P<0.05)$. For glucose plasma level, the lean chickens fed the HL diet exhibited the highest value and the fat chickens fed the HL diet exhibited the lowest value $(P<0.05)$.

\section{Plasma Metabolomics Analysis}

Table 4 summarizes the results of the multivariate (PLS-DA) and univariate analyses. All models were predictive except for the comparison between the fatHL and lean-HL groups. The most predictive model was obtained for line comparison (fat-lean) as illus- trated in Fig. 1 with the first 3 principal partial least squares (PLS) components having a good predictive value $\left(\mathrm{Q}^{2}=0.79\right.$ and $R^{2} \mathrm{Y}=0.89$; Table 4$)$. The first and second PLS components clearly separated the 2 experimental chicken lines (Fig. 1A) with cross- validated ANOVA $\left(P\right.$-value $\left.=910^{-8}\right)$ response permutation test (Fig. 1C) indicating the robustness of the model. The metabolites mostly implicated in the line discrimination were glutamine, histidine, and betaine (Fig. 1B and 2). The lean chickens exhibited lower plasma levels in betaine, creatine, (LDL), methionine, praline, and threonine but higher plasma levels for glucose, glutamine, histidine, and lysine than fat chickens (Fig. 2; Table 5). For the diet effect, the most discriminating metabolites were lipids, LDL, and methionine (Fig. 2). The chickens fed the HL diet exhibited higher plasma levels for 10 metabolites and lower levels for acetoacetate, LDL, and betaine than chickens fed the LL diet (Fig. 2; Table 5). The diet and line had no effect on high-density lipoprotein (HDL) and very-low-density lipoprotein (VLDL) plasma levels.

Table 2. Plasma concentrations of metabolites and hormones measured at $20 \mathrm{~d}$ of age in chickens from fat and lean lines and fed with the same starting diet $($ mean $\pm \mathrm{SE} ; n=10)$

\begin{tabular}{lllc}
\hline \hline Parameters & \multicolumn{1}{c}{ Fat } & \multicolumn{1}{c}{ Lean } & Line effect \\
\hline Total cholesterol, mg/L & $1,244 \pm 99$ & $1,293 \pm 103$ & 0.29 \\
Phospholipids, $\mathrm{mg} / \mathrm{mL}$ & $2.00 \pm 0.27^{\mathrm{b}}$ & $2.22 \pm 0.19^{\mathrm{a}}$ & 0.06 \\
Triglycerides, $\mathrm{mg} / \mathrm{L}$ & $374 \pm 53^{\mathrm{b}}$ & $454 \pm 112^{\mathrm{a}}$ & 0.05 \\
Free fatty acids, $\mu \mathrm{mol} / \mathrm{L}$ & $128 \pm 27$ & $135 \pm 31$ & 0.56 \\
Glucose, $\mathrm{mg} / \mathrm{L}$ & $2,378 \pm 118^{\mathrm{b}}$ & $2,661 \pm 180^{\mathrm{a}}$ & 0.0006 \\
Lactate, $\mu \mathrm{mo} / \mathrm{L}$ & $9,317 \pm 1,724$ & $9,738 \pm 1,953$ & 0.62 \\
Uric acid, mg/L & $88 \pm 18$ & $75 \pm 30$ & 0.25 \\
$\beta$-hydroxybutyrate, $\mu \mathrm{mol} / \mathrm{L}$ & $461+114^{\mathrm{b}}$ & $557+104^{\mathrm{a}}$ & 0.06 \\
Urea, $\mathrm{mg} / \mathrm{L}$ & $22.5 \pm 3.6$ & $23.1 \pm 5.9$ & 0.79 \\
T3 ${ }^{1}{ }^{\mathrm{pmmol} / \mathrm{mL}}$ & $2.72 \pm 0.58$ & $2.46 \pm 0.46$ & 0.27 \\
T4 ${ }^{1}{ }^{\mathrm{pmmol} / \mathrm{mL}}$ & $8.62 \pm 1.74^{\mathrm{a}}$ & $6.91 \pm 1.60^{\mathrm{b}}$ & 0.03 \\
Insulin, microunits/mL & $59.8 \pm 35.0$ & $60.5 \pm 35.8$ & 0.97 \\
\hline
\end{tabular}

${ }^{\mathrm{a}, \mathrm{b}}$ Means within a row with different superscripts differ $(P<0.05)$.

${ }^{1} \mathrm{~T} 3=$ triiodothyronine; $\mathrm{T} 4=$ thyroxin. 
An interaction $(P<0.05)$ between the line and diet was also found for choline, citrate, HDL, isoleucine, lysine, methionine, and valine (Table 5).

\section{Regression Analyses between Plasma Parameters and Body Composition}

Only significant associations are shown in Table 6. Results concerning the relative weights of abdominal fat and of FTET were rather similar except for $\beta$-hydroxybutyrate, which was associated to only abdominal fat. A positive correlation $(P<0.05)$ was found between the proportions of adipose tissues and plasma uric acid, phospholipid, triglyceride, and betaine levels. A negative correlation $(P<0.05)$ was found between the proportions of adipose tissues and plasma T3, homocysteine, glutamine, and histidine levels.

For muscles, significant relationships were observed between plasma parameters and the relative weight of PM muscle whereas the correlations were not significant for SART muscle. A positive correlation $(P<0.05)$ was observed between the relative weight of PM muscle and plasma T3, glutamine, and histidine levels. A negative correlation $(P<0.05)$ was observed between PM muscle and plasma phospholipid and triglyceride levels.

No significant correlation was observed between the relative weight of muscle or adipose tissues and plasma FFA, lactate, urea, glucose, total cholesterol, $\mathrm{T} 4$, insulin, and methionine levels.

Various combinations of 2 to 6 plasma parameters explained a significant $(P<0.05)$ part of the variation in body fat content. Plasma glutamine, total cholesterol, FFA, phospholipid, methionine, and $\beta$-hydroxybutyrate levels accounted for $74 \%$ of the variability of the relative weight of abdominal fat (Table 7). The relative contribution of each metabolite, respecting the previous order, was $44.54,0.46,4.89,12.51$, and $12.14 \%$, respectively. Moreover, plasma triglyceride and homocysteine levels accounted for $37 \%$ of the variability of FTET (Table 7), with the relative contribution of each metabolite being 24.76 and $12.20 \%$, respectively. Contrary to adipose tissues, multiple regression analyses did not improve the predictive power of plasma parameters in explaining the variation in the relative weights of PM or SART muscles.

\section{DISCUSSION}

Lean chickens had higher plasma levels of triglycerides at $20 \mathrm{~d}$ of age but lower triglyceridemia at $63 \mathrm{~d}$ of age than fat chickens. Blood samples were collected at $20 \mathrm{~d}$ without any feed withdrawal before whereas blood collection was performed in fastedrefed chickens at $63 \mathrm{~d}$. The uptake of plasma lipids by peripheral tissues may be less efficient for lean chick-

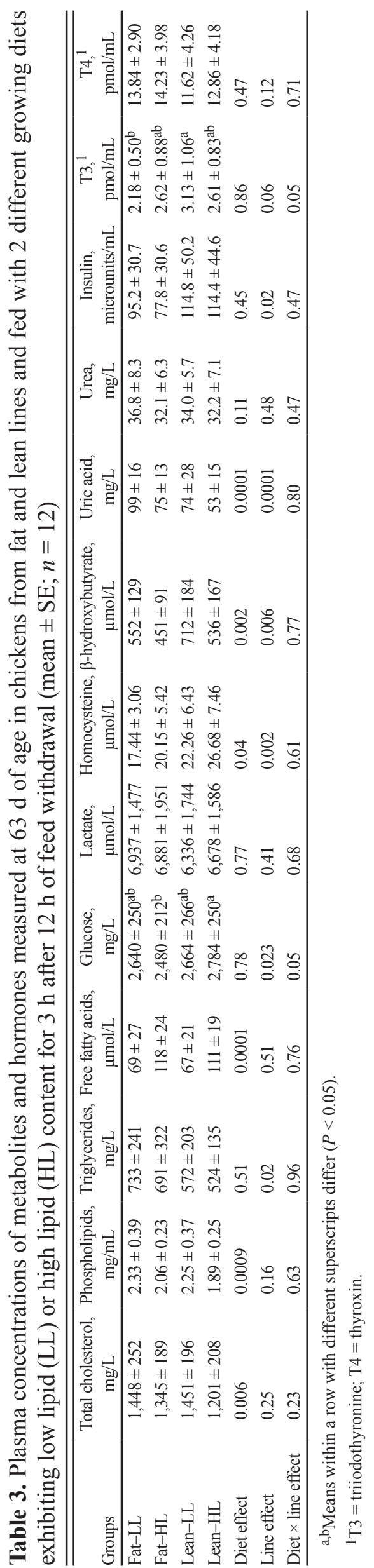


Table 4. Results of the multivariate (partial least squares-discriminant analysis) and univariate analyses of proton nuclear magnetic resonance data

\begin{tabular}{|c|c|c|c|c|c|c|c|c|}
\hline \multirow[b]{2}{*}{ Comparisons $^{1}$} & \multirow[b]{2}{*}{$\begin{array}{l}\text { Number } \\
\text { of samples }\end{array}$} & \multicolumn{6}{|c|}{ Model characteristics and validation ${ }^{2}$} & \multirow[b]{2}{*}{$\begin{array}{c}\text { Discriminating metabolites }{ }^{3} \\
\text { (evolution first group vs. second; } P \text {-value) }\end{array}$} \\
\hline & & $\begin{array}{c}\begin{array}{c}\text { Number } \\
\text { of axes }\end{array}\end{array}$ & $R^{2} \mathrm{X}$ & $R^{2} \mathrm{Y}$ & $Q^{2}$ & $\begin{array}{c}\mathrm{CV}^{2}- \\
\text { ANOVA }\end{array}$ & $\begin{array}{c}\text { Permutation } \\
\text { test }\end{array}$ & \\
\hline$\overline{\text { Fat-LL/Fat-HL }}$ & $11 / 12$ & 2 & 0.42 & 0.87 & 0.67 & $6.3 \times 10^{-4}$ & Yes & Lipids $\left(\downarrow ; \geq 4.9 \times 10^{-6}\right)$, Met $\left(\downarrow ; 3 \times 10^{-8}\right)$, and LDL $\left(\uparrow ; 2.2 \times 10^{-6}\right)$ \\
\hline Lean-LL/Lean-HL & $12 / 12$ & 1 & 0.18 & 0.78 & 0.55 & $2.2 \times 10^{-4}$ & No & Lipids $\left(\downarrow ; \geq 6.2 \times 10^{-4}\right)$ and $\operatorname{LDL}\left(\uparrow ; \geq 3.4 \times 10^{-4}\right)$ \\
\hline Fat-LL/Lean-LL & $11 / 12$ & 2 & 0.43 & 0.84 & 0.53 & $1.8 \times 10^{-2}$ & No & $\operatorname{Gln}\left(\downarrow ; \geq 4.5 \times 10^{-7}\right)$, His $\left(\downarrow ; \geq 1.8 \times 10^{-5}\right)$, and Bet $\left(\uparrow ; \geq 9.7 \times 10^{-3}\right)$ \\
\hline Fat-HL/Lean-HL & $12 / 12$ & 2 & 0.31 & 0.87 & 0.46 & 0.34 & No & - \\
\hline Fat/lean & $23 / 24$ & 3 & 0.47 & 0.89 & 0.79 & $9 \times 10^{-8}$ & Yes & $\operatorname{Gln}\left(\downarrow ; \geq 1.6 \times 10^{-9}\right)$, His $\left(\downarrow ; \geq 7.5 \times 10^{-7}\right)$, and Bet $\left(\uparrow ; \geq 9.9 \times 10^{-5}\right)$ \\
\hline$L L / H L$ & $23 / 24$ & 3 & 0.51 & 0.87 & 0.74 & $5.3 \times 10^{-9}$ & Yes & Lipids $\left(\downarrow ; \geq 8.4 \times 10^{-8}\right)$, Met $\left(\downarrow ; 8.5 \times 10^{-5}\right)$, and LDL $\left(\uparrow ; 2.3 \times 10^{-6}\right)$ \\
\hline
\end{tabular}

${ }^{1} \mathrm{LL}=$ low lipid; $\mathrm{HL}=$ high lipid.

${ }^{2} R^{2} \mathrm{X}=$ proportion of the total variance of the dependent variables that is explained by the model; $\mathrm{R}^{2} \mathrm{Y}=$ response variable explained by the model; $\mathrm{Q}^{2}=$ predictive ability parameter of the model.

${ }^{3} \mathrm{LDL}=$ low-density lipoprotein; Bet $=$ betaine; Met = methionine; Gln = glutamine; His $=$ histidine; $\downarrow=$ decreased; $\uparrow=$ increased.

Table 5. Plasma metabolomics analysis determined at $63 \mathrm{~d}$ of age in chickens from fat and lean lines and fed with 2 different growing diets exhibiting low lipid (LL) or high lipid (HL) content for $3 \mathrm{~h}$ after $12 \mathrm{~h}$ of feed withdrawal $(n=12)$

\begin{tabular}{|c|c|c|c|}
\hline Metabolites & Line effect & Diet effect & Line $\times$ diet effect \\
\hline Acetoacetate & $\mathrm{ns}^{1}$ & $0.004(\mathrm{LL}>\mathrm{HL})$ & ns \\
\hline Acetone & ns & ns & ns \\
\hline Alanine & ns & ns & $\mathrm{ns}$ \\
\hline Betaine & 0.0001 (lean < fat) & $0.05(\mathrm{LL}>\mathrm{HL})$ & $\mathrm{ns}$ \\
\hline Choline & ns & $0.03(\mathrm{LL}<\mathrm{HL})$ & 0.04 \\
\hline Citrate & ns & $0.05(\mathrm{LL}<\mathrm{HL})$ & 0.02 \\
\hline Creatine & 0.01 (lean < fat) & ns & $\mathrm{ns}$ \\
\hline Formate & ns & ns & $\mathrm{ns}$ \\
\hline Fumarate & ns & ns & $\mathrm{ns}$ \\
\hline Glucose & 0.01 (lean > fat) & $0.001(\mathrm{LL}<\mathrm{HL})$ & $\mathrm{ns}$ \\
\hline Glutamine & 0.0001 (lean > fat) & $0.02(\mathrm{LL}<\mathrm{HL})$ & ns \\
\hline Glutamate & $\mathrm{ns}$ & $\mathrm{ns}$ & ns \\
\hline $\mathrm{HDL}^{2}$ & ns & $\mathrm{ns}$ & 0.02 \\
\hline Histidine & 0.0001 (lean > fat) & ns & ns \\
\hline Isoleucine & $\mathrm{ns}$ & $\mathrm{ns}$ & 0.03 \\
\hline Lactate & ns & $\mathrm{ns}$ & ns \\
\hline $\mathrm{LDL}^{3}$ & 0.007 (lean < fat) & $0.0001(\mathrm{LL}>\mathrm{HL})$ & ns \\
\hline Leucine & ns & ns & ns \\
\hline Lysine & 0.02 (lean > fat) & $0.03(\mathrm{LL}<\mathrm{HL})$ & 0.02 \\
\hline Methionine & 0.05 (lean < fat) & $0.0001(\mathrm{LL}<\mathrm{HL})$ & 0.005 \\
\hline myo-Inositol & ns & $0.0001(\mathrm{LL}<\mathrm{HL})$ & ns \\
\hline Phenylalanine & ns & $0.0001(\mathrm{LL}<\mathrm{HL})$ & $\mathrm{ns}$ \\
\hline Proline & 0.02 (lean < fat) & ns & ns \\
\hline Pyruvate & ns & ns & ns \\
\hline Succinate & ns & ns & $\mathrm{ns}$ \\
\hline Threonine & 0.05 (lean < fat) & $0.03(\mathrm{LL}<\mathrm{HL})$ & $\mathrm{ns}$ \\
\hline Tyrosine & ns & $0.0001(\mathrm{LL}<\mathrm{HL})$ & ns \\
\hline Valine & ns & ns & 0.02 \\
\hline VLDL $^{4}$ & ns & ns & $\mathrm{ns}$ \\
\hline
\end{tabular}

ens than for fat chickens. However, we found no line effect on VLDL and HDL plasma levels at $63 \mathrm{~d}$ of age. Therefore, these data suggest a line effect on the composition of lipoproteins. Saez et al. (2012) showed that Pekin ducks exhibiting a high ability to store lipids in peripheral tissues had higher triglyceride content in VLDL than Muscovy ducks. The higher plasma level of LDL for fat chickens could not be induced by a lower ability of peripheral tissues for circulating lipid uptake as the highest amount of fatty tissue allowed the birds of this line to exhibit a higher activity of plasma lipoprotein lipase (Hermier et al., 1989). It suggests only that the amount of circulating lipids returning to the liver was higher for fat chickens. However, the lipid content of liver was similar for the 2 lines (Baéza et al., 2014). As previously reported (Baéza and Le BihanDuval, 2013), the plasma glucose level was higher for lean chickens at 21 and $63 \mathrm{~d}$ of age. This is a characteristic of lean birds that has been also described in ducks (Baéza et al., 2005). The fat birds have a higher capacity to metabolize glucose and synthesize glycogen related with higher insulin plasma level even if their ADFI is higher than that of lean chickens. In our study, the plasma insulin level did not differ between lines at $20 \mathrm{~d}$ of age whereas it was higher in lean chickens than in fat chickens at $63 \mathrm{~d}$ of age. This suggests that the postprandial kinetic was different between the 2 lines. Consistently, after a meal, a higher and faster increase in plasma insulin was reported in fat birds whereas the decrease was slower in lean birds (Baéza et al., 2005; Baéza and Le Bihan-Duval, 2013), which could explain a higher plasma level of insulin $3 \mathrm{~h}$ after the beginning of meal for lean chickens. The plasma level of $\beta$-hydroxybutyrate was also higher for lean chickens at $63 \mathrm{~d}$ of age, confirming their higher ability for liver lipid oxidation (Baéza et al., 2014) and partly explaining the lower carcass fatness for this line. Moreover, this parameter had a negative correlation 

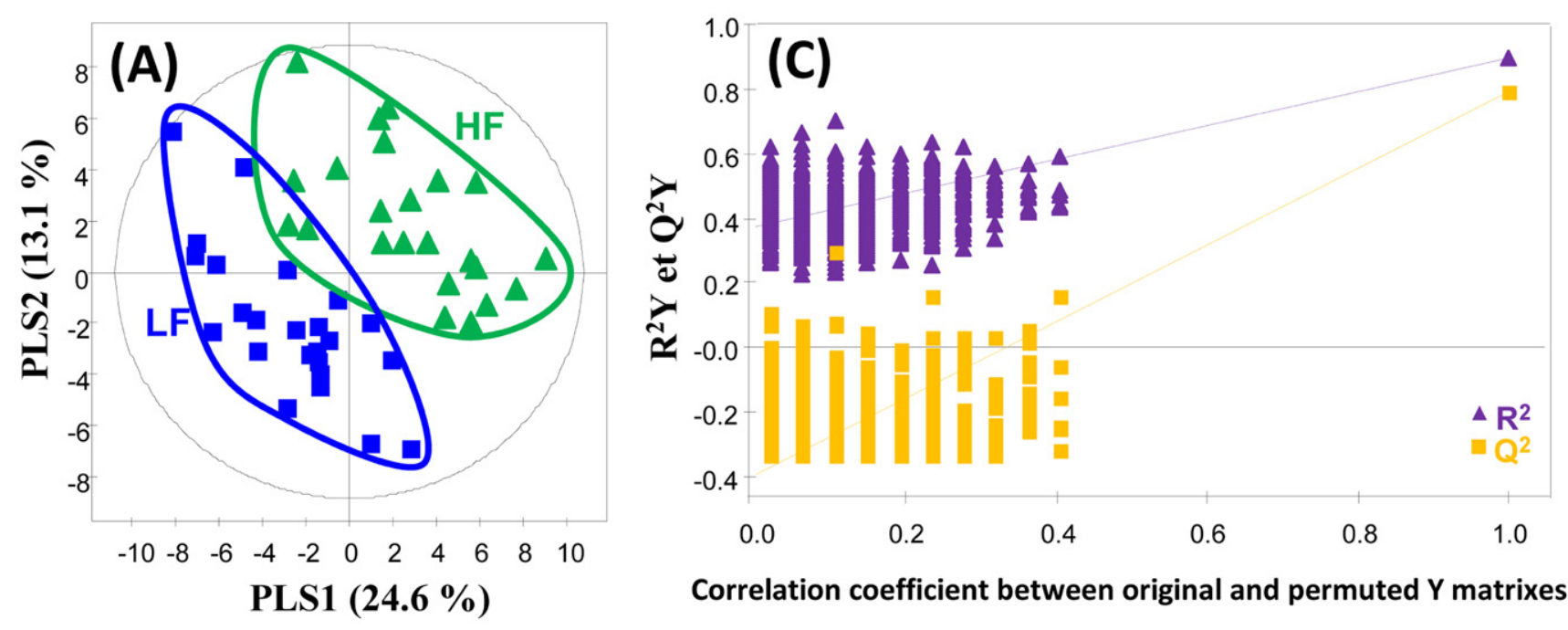

Correlation coefficient between original and permuted $\mathrm{Y}$ matrixes

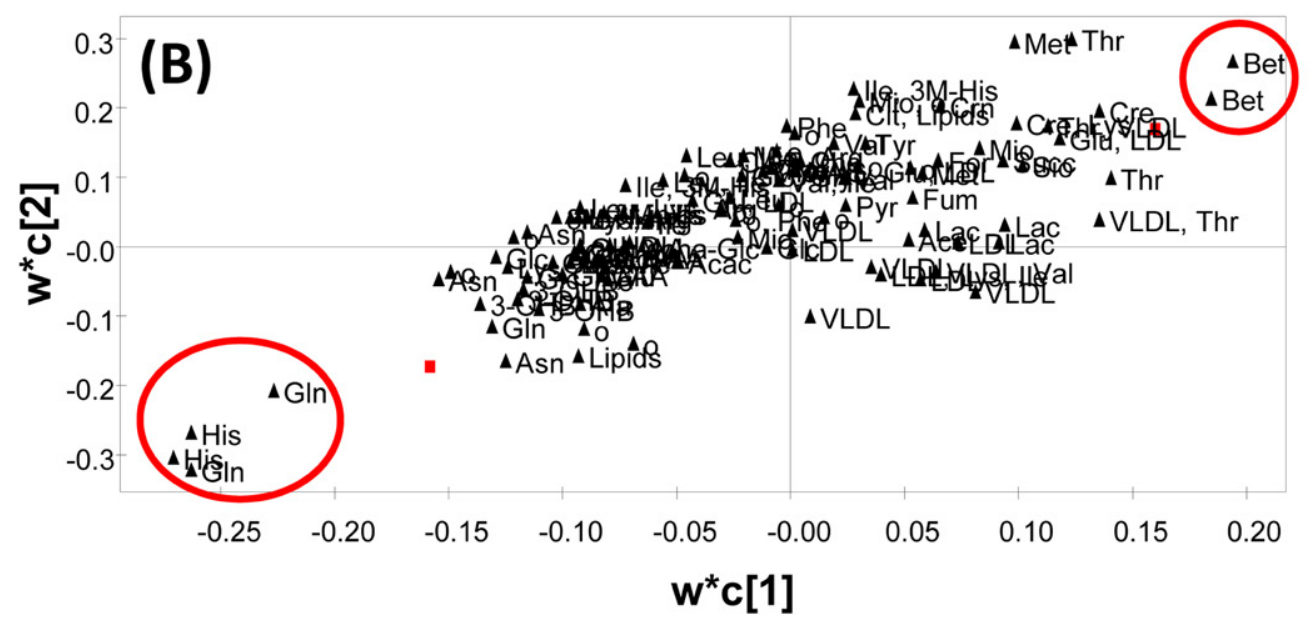

Figure 1. Partial least squares-discriminant analysis (PLS-DA) of the proton nuclear magnetic resonance data of fat (HF) and lean (LF) lines. (A) Score plot (distribution of individuals) of the PLS-DA along the 2 principal partial least squares (PLS) axes. (B) Loading plot (distribution of variables) of PLS-DA. The main discriminating metabolites are surrounded with a red line. (C) Results from the response permutation test ( 999 permutations). $R^{2} X=$ proportion of the total variance of the dependent variables that is explained by the model; $\mathrm{R}^{2} \mathrm{Y}=$ response variable explained by the model; $\mathrm{Q}^{2}=$ predictive ability parameter of the model; $\mathrm{W} \mathrm{x} \mathrm{C1}$ and $\mathrm{W}$ x $\mathrm{C} 2=$ loading plot of principal components 1 and 2; $\mathrm{HDL}=$ high-density lipoproteins; LDL = low-density lipoproteins; VLDL = very-low-density lipoproteins

with adipose tissues. Indeed, Skiba-Cassy et al. (2007) showed that in the fed state, lean chickens exhibited greater hepatic carnitine palmitoyltransferase 1 level and $\beta$-hydroxyacyl-CoA dehydrogenase mRNA expressions in the liver than fat chickens. Resnyk et al. (2013) also found a higher expression of genes implicated in lipolysis in the abdominal fat of lean chickens than in that of fat chickens. The previously described lower T4 plasma level in lean chickens (Baéza and Le Bihan-Duval, 2013) was also observed in the present study at $20 \mathrm{~d}$ of age. Plasma T4 level could reflect the hypothalamic control of body composition for these lines (Byerly et al., 2009, 2010). The lower plasma levels of glutamine and histidine for fat chickens suggest that these AA may have been used to produce glucose. Furthermore, glutamine and histidine were highly negatively correlated with adipose tissues. Different studies have reported that fat chickens had lower plasma levels of glucogenic AA and higher levels of branched-chain and sulfur AA (Géraert et al., 1987; Leclercq et al., 1993). However, in our study, the plasma levels of others glucogenic AA (methionine, threonine, and proline) were higher for fat chickens. In this line, the plasma level of lysine was lower, suggesting its use to produce energy, whereas, the plasma level of creatine was higher, suggesting a higher hepatic synthesis of this AA to provide energy for muscles. Moreover, the plasma level of uric acid was higher and positively correlated to adipose tissue, suggesting a higher protein oxidation for fat chickens and explaining their lower muscle development. On the other hand, Alleman et al. (1999) found greater glutamate dehydrogenase activity in the livers of fasted fat chickens than in those of lean chickens. Finally, it seems that the metabolism of methionine was also affected, as lean chickens presented lower plasma me- 
Table 6. Significant correlations between the proportion of abdominal fat, fat situated at the top of external face of the thigh (FTET), or pectoralis major muscle relative to body weight and plasma parameters $(n=48)$

\begin{tabular}{|c|c|c|c|c|c|c|}
\hline \multirow{3}{*}{$\begin{array}{l}\text { Plasma } \\
\text { parameter }\end{array}$} & \multicolumn{4}{|c|}{ Adipose tissue } & \multirow{2}{*}{\multicolumn{2}{|c|}{$\begin{array}{c}\text { Muscle } \\
\text { Pectoralis major }\end{array}$}} \\
\hline & \multicolumn{2}{|c|}{ Abdominal fat } & \multicolumn{2}{|c|}{ FTET } & & \\
\hline & $r$ & $P$-value & $r$ & $P$-value & $r$ & $P$-value \\
\hline Uric acid & 0.43 & $<0.01$ & 0.44 & $<0.01$ & -0.12 & $>0.1$ \\
\hline Phospholipids & 0.26 & $<0.1$ & 0.38 & $<0.01$ & -0.31 & $<0.05$ \\
\hline Triglycerides & 0.47 & $<0.001$ & 0.51 & $<0.001$ & -0.47 & $<0.001$ \\
\hline$\beta$-hydroxybutyrate & -0.35 & $<0.05$ & -0.18 & $>0.1$ & 0.17 & $>0.1$ \\
\hline $\mathrm{T}^{1}$ & -0.38 & $<0.01$ & -0.41 & $<0.01$ & 0.29 & $<0.05$ \\
\hline Homocysteine & -0.47 & $<0.001$ & -0.43 & $<0.01$ & 0.20 & $>0.1$ \\
\hline Betaine & 0.45 & $<0.01$ & 0.36 & $<0.05$ & -0.20 & $>0.1$ \\
\hline Glutamine & -0.67 & $<0.001$ & -0.45 & $<0.01$ & 0.27 & $<0.1$ \\
\hline Histidine & -0.71 & $<0.001$ & -0.52 & $<0.05$ & 0.39 & $<0.01$ \\
\hline $\mathrm{LDL}^{2}$ & 0.16 & $>0.1$ & 0.30 & $>0.1$ & -0.26 & $>0.1$ \\
\hline
\end{tabular}

${ }^{1} \mathrm{~T} 3=$ triiodothyronine.

${ }^{2} \mathrm{LDL}=$ low-density lipoproteins.
Table 7. Multiple regression model for adipose and muscle tissues using whole plasmatic parameters data $(n=48)$

\begin{tabular}{lccc}
\hline \hline Parameter & Estimate $^{1}$ & $P$-value & $r^{2}$ \\
\hline Abdominal fat & & & 0.74 \\
Intercept & 4.4 & 0.07 & \\
$\beta$-hydroxybutyrate & -0.003 & $<0.001$ & \\
Free fatty acids & -0.01 & $<0.01$ & \\
Glutamine & -0.001 & $<0.001$ & \\
Methionine & 3,640 & $<0.001$ & \\
Phospholipids & 3.0 & $<0.001$ & \\
Total cholesterol & -0.004 & $<0.001$ & \\
FTET & & & 0.37 \\
Intercept & 0.28 & $<0.05$ & \\
Triglycerides & 0.0004 & $<0.001$ & \\
Homocysteine & -0.009 & $<0.01$ & \\
\hline
\end{tabular}

${ }^{1}$ Estimate and $P$-value of each parameter in the model established by exhaustive search.

${ }^{2}$ FTET $=$ fat situated on the top of the external face of the thigh.

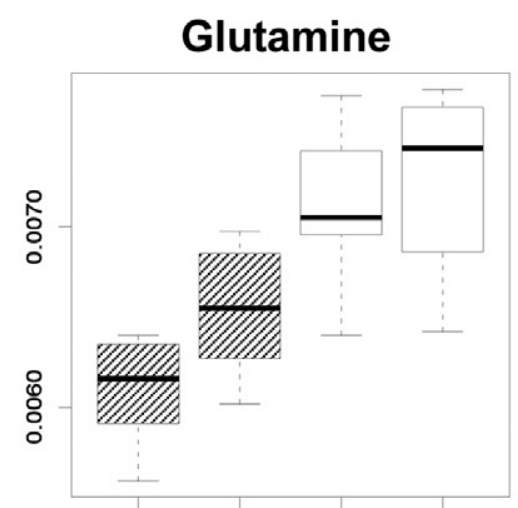

HF-LL HF-HL LF-LL LF-HL

L effect : $P=0.0001$

D effect: $P=0.02$

$D \times$ L effect: $P=0.14$

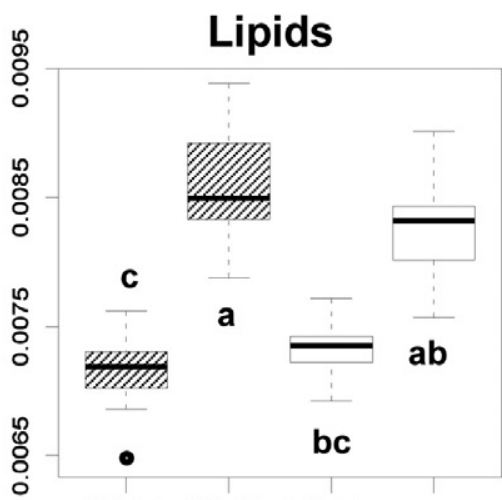

HF-LL HF-HL LF-LL LF-HL

$$
\begin{aligned}
& \text { L effect : } P=0.40 \\
& \text { D effect: } P=0.0001 \\
& \text { D x L effect: } P=0.02
\end{aligned}
$$

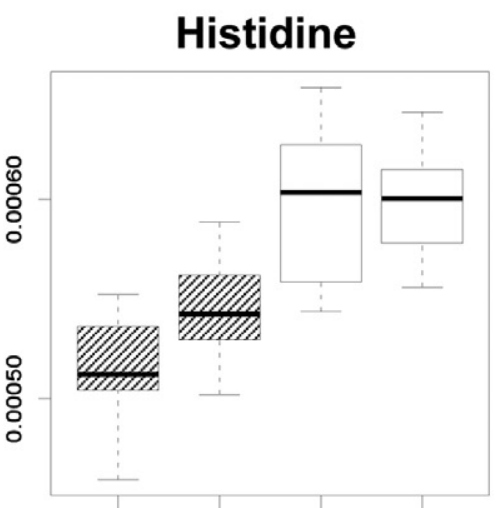

HF-LL HF-HL LF-LL LF-HL

$$
\begin{aligned}
& \text { L effect : } P=0.0001 \\
& \text { D effect: } P=0.08 \\
& \text { D x L effect: } P=0.11
\end{aligned}
$$

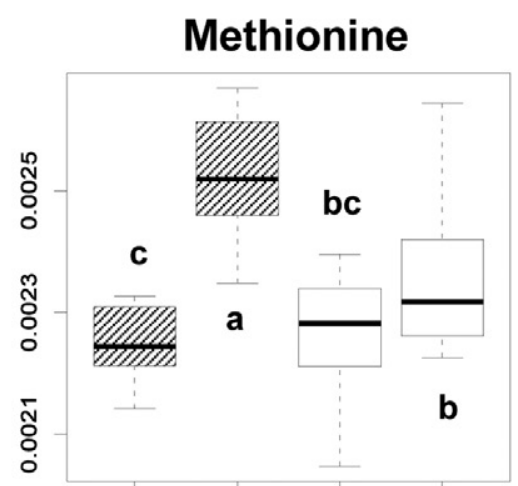

HF-LL HF-HL LF-LL LF-HL

$$
\begin{aligned}
& \text { L effect : } P=0.01 \\
& \text { D effect: } P=0.0001 \\
& \text { D x L effect: } P=0.005
\end{aligned}
$$

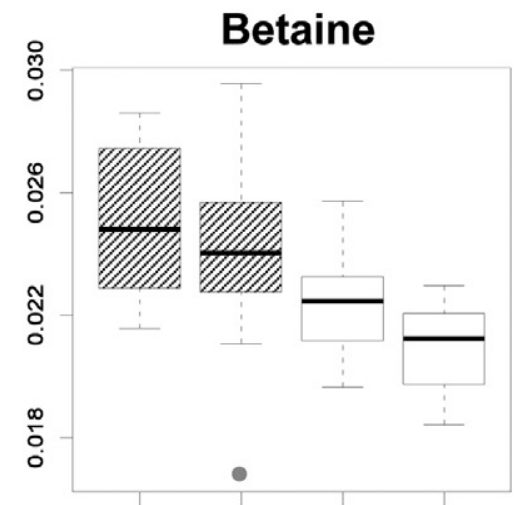

HF-LL HF-HL LF-LL LF-HL

L effect : $P=0.0001$

D effect: $P=0.05$

D x L effect: $P=0.74$

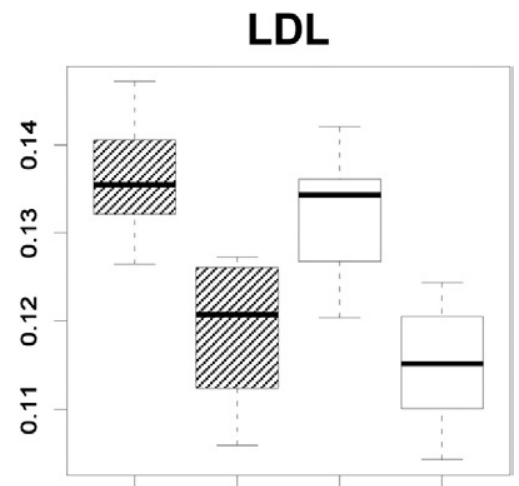

HF-LL HF-HL LF-LL LF-HL

$$
\begin{aligned}
& \text { L effect : } P=0.06 \\
& \text { D effect: } P=0.0001 \\
& \text { D x L effect: } P=0.80
\end{aligned}
$$

Figure 2. Plasma metabolomics analysis determined at $63 \mathrm{~d}$ of age in chickens from fat (HF) and lean (LF) lines and fed with two growing diets exhibiting low (LL) or high (HL) lipid content for $3 \mathrm{~h}$ after $12 \mathrm{~h}$ of feed withdrawal $(\mathrm{n}=12)$. Boxplots of glutamine, betaine, methionine, histidine, lipids and low-density lipoproteins (LDL). a,c: differences between groups when the interaction between diet and line had a significant effect with $P<0.05$. 
thionine and betaine and higher homocysteine levels than fat chickens. Consequently, high body fatness is clearly related to a greater use of glucose toward lipid synthesis, a low ability for lipid oxidation, and a high ability for protein oxidation and the use of glucogenic AA toward lipid synthesis. Therefore, plasma parameters related to or resulted from these mechanisms will be pertinent indicators of body fatness.

Data on plasma parameters suggested an effect of diet on lipid and protein metabolisms. Even if the diet had no effect on VLDL and HDL plasma levels, the finding of higher plasma total cholesterol and phospholipids levels in chickens fed the LL diet compared with chickens fed the HL diet suggests that the lipid composition of lipoproteins was affected by the dietary energy source as diets were isoenergetic and isoproteic and had no effect on the amount of feed ingested. The LL diet providing lower levels of lipids reduced plasma level of FFA whereas the lipid oxidation seemed to be higher, as the plasma levels of $\beta$-hydroxybutyrate and acetoacetate, 2 ketone bodies, were higher. Indeed, Baéza et al. (2014) showed that the activity of oxidative enzymes was higher in the liver of chickens fed the LL diet by comparison with the chickens fed the HL diet. The lower plasma level of LDL induced by the LL diet suggests that peripheral tissues may exhibit a higher ability for circulating lipid uptake. Apart from lipids, discrimination between dietary groups was also clearly related to plasma methionine level. In addition, dietary groups also differed for plasma levels in lysine, phenylalanine, threonine, tyrosine, and glutamine. This indicated an effect of dietary nutrients on AA metabolism. In chickens fed the LL diet, these AA could have been used to produce glucose or ketone bodies. Indeed, lysine can be used to produce acetyl CoA that is implicated as citrate in the production of energy. Plasma levels of these 2 metabolites were also lower for chickens fed the LL diet. Moreover, the plasma level of uric acid was higher, suggesting a higher protein oxidation with the LL diet. Finally, the metabolism of methionine seems to be also affected, as chickens fed the LL diet had lower plasma levels of methionine, choline, and homocysteine and a higher level of betaine. Consequently, the LL diet stimulated lipid synthesis not only from carbohydrates but also from glucogenic AA and lipid oxidation. What is remarkable is that even if the dietary energy source had an effect on the energy and protein metabolisms of birds, within each line chickens exhibited the same body fatness.

The dietary source of energy affected both energy and protein metabolisms. These mechanisms will be further investigated with transcriptomic and targeted approaches (gene expression, signaling pathways, etc.) on different tissues (liver, muscle, and abdominal fat) and blood. Regarding the genetic ability to synthesize and store lipids in the peripheral tissues, lower plasma glucose and $\beta$-hydroxybutyrate levels can be considered good indicators. On the other hand, plasma levels of insulin and lipids depending on bird age, nutritional status, and/or postprandial delay should not be retained. The potential use of other plasma parameters such as methionine, betaine, glutamine, histidine, homocysteine, uric acid, and T4 as indicators of body fatness remains to be further investigated.

\section{LITERATURE CITED}

Alleman, F., A. Bordas, J.P. Caffin, S. Daval, C. Diot, M. Douaire, J.M. Fraslin, S. Lagarrigue and B. Leclercq. 1999. L'engraissement chez le poulet : aspects métaboliques et génétiques. INRA Prod. Anim. 12:257-264.

Anderssen, E., K. Dyrstad, F. Westad, and H. Martens. 2006. Reducing over-optimism in variable selection by cross-model validation. Chemom. Intell. Lab. Syst. 84:69-74.

Baéza, E., and E. Le Bihan-Duval. 2013. Chicken lines divergent for low or high abdominal fat deposition: A relevant model to study the regulation of energy metabolism. Animal 7(6):965-973.

Baéza E., N. Rideau, P. Chartrin, S. Davail, R. Hoo-Paris, J. Mourot, G. Guy, M.D. Bernadet, H. Juin, K. Méteau and D. Hermier. 2005. Canards de Barbarie, Pékin et leurs hybrides : aptitude à l'engraissement. INRA Prod. Anim. 18 (2):131-141.

Baéza E., P. Chartrin, A. Collin, S. Métayer-Coustard, C. Berri, I. Gabriel, A. Narcy, M. Lessire, M. Jegou, E., Le Bihan-Duval, S. Lagarrigue F. Gondret, and M.J. Duclos. 2014. Performance, carcass traits and meat quality of genetically fat and lean broilers are unaffected by dietary energy source. In proceedings XIVth WPSA European Poultry Conference, Stavanger, Norway, June 23-26, 2014: 4 p.

Bourneuf, E., F. Hérault, C. Chicault, W. Carre, S. Assaf, A. Monnier, S. Mottier, S. Lagarrigue, M. Douaire, J. Mosser, and C. Diot. 2006. Microarray analysis of differential gene expression in the liver of lean and fat chickens. Gene 372:162-170.

Byerly, M. S., J. Simon, L. A. Cogburn, E. Le Bihan-Duval, M. J. Duclos, S. Aggray, and T. E. Porter. 2010. Transcriptional profiling of hypothalamus during development of adiposity in genetically selected fat and lean chickens. Physiol. Genomics 42:157-167.

Byerly, M. S., J. Simon, E. Le Bihan-Duval, M. J. Duclos, L. A. Cogburn, and T. E. Porter. 2009. Effects of BDNF, T3 and corticosterone on expression of the hypothalamic obesity gene network in vivo and in vitro. Am. J. Physiol. Regul. Integr. Comp. Physiol. 296:R1180-R1189.

Eriksson, L., J. Trygg, and S. Wold. 2008. CV-ANOVA for significance testing of PLS and OPLS models. J. Chemometr. 22:594-600.

Géraert, P. A., B. Leclercq, and M. Larbier. 1987. Effects of dietary glucogenic amino acid supplementation on growth performance, body composition and plasma free amino acid levels in genetically lean and fat chickens. Reprod. Nut. Dev. 27(6):1041-1051.

Hardie, D. G., F. A. Ross, and S. A. Hawley. 2012. AMPK: A nutrient and energy sensor that maintains energy homeostasis. Nat. Rev. Mol. Cell Biol. 13(4):251-262.

Hermier, D., A. Quignard-Boulange, I. Dugail, G. Guy, M. R. Salichon, L. Brigant, B. Ardouin, and B. Leclercq. 1989. Evidence of enhanced storage capacity in adipose tissue of genetically fat chickens. J. Nutr. 119:1369-1375. 
Huber, M., L. P. L. Van de Vijver, H. Parmentier, H. Savelkoul, L. Coulier, S. Wopereis, E. Verheij, J. Van der Greef, D. Nierop, and R. A. P. Hoogenboom. 2010. Effects of organically and conventionally produced feed on biomarkers of health in a chicken model. Br. J. Nutr. 103:663-676.

Lagarrigue, S., F. Pitel, W. Carre, B. Abasht, P. Le Roy, A. Neau, Y. Amigues, M. Sourdioux, J. Simon, L. Cogburn, S. Aggrey, B. Leclercq, A. Vignal, and M. Douaire. 2006. Mapping quantitative trait loci affecting fatness and breast muscle weight in meat-type chicken lines divergently selected on abdominal fatness. Genet. Sel. Evol. 38(1):85-97.

Leclercq, B. 1988. Genetic selection of meat-type chickens for high or low abdominal fat content. In: B. Leclercq and C. C. Whitehead, editors, Leanness in domestic birds: Genetic, metabolic and hormonal aspects. Butterworths \& Co, LtdINRA, London, UK. p. 25-40.

Leclercq, B., A. M. Chagneau, T. Cochard, S. Hamzaoui, and M. Larbier. 1993. Comparative utilization of sulphur-containing amino-acids by genetically lean or fat chickens. Br. Poult. Sci. 34(2):383-391.

Leclercq, B., J. Simon, and F. H. Ricard. 1987. Effects of selection for high and low blood plasma glucose concentration in chickens. Br. Poult. Sci. 28:557-565.

R Development Core Team. 2008. R: A language and environment for statistical computing. R Foundation for Statistical Computing, Vienna, Austria. www.R-project.org. (Accessed 20 May 2004).
Resnyk, C. W., W. Carré, X. Wang, T. E. Porter, J. Simon, E. Le Bihan-Duval, M. J. Duclos, S. E. Aggrey, and L. A. Cogburn. 2013. Transcriptional analysis of abdominal fat in genetically fat and lean chickens reveals adipokines, lipogenic genes and a link between hemostasis and leanness. BMC Genomics 14:557-583.

Saez, G., I. Savary-Auzeloux, E. Baéza, M. D. Bernadet, S. Davail, D. Durand, D. Bauchart, and D. Gruffat. 2012. Fractional apoB-VLDL hepatic synthesis rate in Muscovy and Pekin ducks fed ad libitum. Arch. Geflügelk. 76(1):S20-S25.

Simon, J., P. Freychet, and G. Rosselin. 1974. Chicken insulin: Radioimmunological characterization and enhanced activity in rat fat cells and liver plasma membranes. Endocrinology 95:1439-1449.

Skiba-Cassy, S., A. Collin, P. Chartrin, F. Médale, J. Simon, M. J. Duclos, and S. Tesseraud. 2007. Chicken liver and muscle carnitine palmitoyltransferase 1: Nutritional regulation of messengers. Comp. Biochem. Physiol. B Biochem. Mol. Biol. 147:278-287.

Van der Geyten, S., I. Van der Eynde, I. B. Segers, E. R. Kuhn, and V. M. Darras. 2002. Differential expression of iodothyronine deiodinases in chicken tissues during the last week of embryonic development. Gen. Comp. Endocrinol. 128:65-73. 